\title{
HUBUNGAN LAMA MENSTRUASI DAN STATUS GIZI DENGAN KEJADIAN ANEMIA PADA REMAJA PUTRI
}

\author{
Dewi Sumdika Sari ${ }^{1,}$ Herawati $^{2}$, Rizki Amalia ${ }^{3}$ \\ Program Studi Diploma IV Kebidanan Universitas Kader Bangsa Palembang \\ Jl. Mayjend. H.M Ryacudu No.88 Palembang Telp (0711)517744-510173 \\ Email : Sumdikadewi17@gmail.com
}

\begin{abstract}
Abstrak
Anemia adalah suatu kondisi tubuh yang terjadi ketika sel-sel darah merah (eritrosit) dan/atau Hemoglobin $(\mathrm{Hb})$ yang sehat dalam darah berada dibawah nilai normal (kurang darah), perempuan < $12 \mathrm{gr} / \mathrm{dl}$. Penelitian ini bertujuan untuk mengetahui hubungan Lama Menstruasi dan Status Gizi dengan Kejadian Anemia pada Remaja Putri kelas XI di SMA N I Martapura Kabupaten Ogan Komering Ulu Timur Tahun 2019. Metode yang digunakan dalam penelitian ini adalah survey analitik dengan pendekatan cross sectional. Uji statistik yang digunakan uji chi-square. Peneliti ini menggunakan data primer dengan populasi 180 responden dan jumlah sampel diambil sebagian jumlah populasi yang berjumlah 64 orang. Dari hasil uji statistik didapatkan adanya hubungan lama menstruasi dengan kejadian anemia. Dengan analisis bivariat hasil uji chi-square diperoleh $P_{\text {value }}(0,034)<\alpha(0,05)$ dan ada hubungan status gizi dengan kejadian anemia. Dengan analisis bivariat hasil uji chi-square diperoleh $P_{\text {value }}(0,000)<\alpha(0,05)$. Hasil dari penelitian ini diharapkan agar remaja putri mengetahui apa saja penyebab yang bisa terjadinya anemia.
\end{abstract}

Kata Kunci $\quad$ : Anemia, Lama Menstruasi, Status Gizi

\begin{abstract}
Anemia is a condition of body when there was health red blood cells (erythrocytes) and/or Hemoglobin $(\mathrm{Hb})$ in blood under normal value (not enough blood), woman $<12 \mathrm{gr} / \mathrm{dl}$. The purpose of this study was to know the relationship among Menstruasi Period and Nutrilional Status with The Incidence Of Anemia in $11^{\text {th }}$ Grades Girls at SHS Number 1 Martapura Kabupaten Ogan Komering Ulu Timur Tahun 2019. The method used in this study was analytic survey with cross sectional approach. The statistical test was chi-square test. The population of this study using primary data data was 180 respondents and the total number of population was half of it 64 people. The statistical test showed that there was relationship between menstrual period and the incidence of anemia. The bivariate analysis chisquare test obtained p.value $(0,034)<\alpha(0,05)$ and there was relationship between nutritional status and the incidence of anemia. The bivariate analysis chi-square test obtained p.value $(0,000)<\alpha(0,05)$. The results of this study are expected to give knowledge about the cause of anemia for all of the teenage girls. Keywords : : Anemia, Menstrual Period, Nutritional Status
\end{abstract}




\section{PENDAHULUAN}

Berdasarkan data world health organization (WHO), Prevalensi anemia pada remaja di dunia bervariasi di beberapa negara berkembang berkisar antara 20-70\%, di negara Myanmar prevalensi anemia ditemukan sebanyak 59,1\% dengan responden 1.269 orang, di Kuala Lumpur, menemukan prevalensi anemia 28,3\% pada remaja putri. Prevalensi anemia yang tinggi terdapat pada negara berpenduduk terbanyak di dunia yaitu India dengan 78, 75\% dengan kasus kebanyakan pada remaja putri (WHO, 2013).

Menurut Riset Kesehatan Dasar (Rikerdas), Prevalensi anemia pada wanita di Indonesia sebesar $44,8 \%$, untuk prevalensi anemia pada wanita umur 5-14 tahun sebesar 26,4\%, sedangkan umur 15-25 tahun sebesar 18,4\% (Rikerdas, 2016).

Jumlah remaja putri di Sumatera Selatan yang berusia 15-18 tahun yang mengalami anemia tahun 2014 sebanyak 571 orang, tahun 2015 sebanyak 756 orang, dan tahun 2016 mencapai 892. Anemia pada remaja putri masih merupakan masalah kesehatan masyarakat dikarenakan prevalensinya lebih dari 15\% (Dinkes Provinsi Sumatera Selatan, 2016).

Studi pendahuluan yang dilakukan oleh peneliti di tetapkan. Jumlah siswi kelas XI di SMA N 1 Martapura Kabupaten Ogan Komering Ulu Timur sebanyak 180 siswi. Berdasarkan hasil pengambilan data awal, siswi yang mengalami anemia di SMA N 1 Martapura Kabupaten Ogan Komering Ulu Timur dari 64 responden didapatkan 19 siswi $(28,1 \%)$, (Data Primer, 2019).

\section{METODE PENELITIAN}

Jenis penelitian ini bersifat kuantitatif dengan menggunakan Survey Analitik dengan pendekatan cross sectional, dimana variabel independen (lama menstruasi dan status gizi) dan variabel dependen (anemia pada remaja putri) diambil atau dikumpulkan dalam waktu bersamaan (Notoatmodjo, 2012).

\section{Jenis Penelitian}

Jenis penelitian ini bersifat kuantitatif dengan menggunakan Survey Analitik dengan pendekatan cross sectional.

\section{Waktu dan Tempat Penelitian}

Penelitian ini Telah dilaksanakan pada bulan Mei - Juni 2019 danPenelitian ini Telah dilaksanakan di SMA N I Martapura Kabupaten Ogan Komering Ulu Timur tahun 2019.

\section{Target/Subjek Penelitian}

Populasi penelitian ini adalah semua remaja putri kelas XI di SMA N I Martapura Kabupaten Ogan Komering Ulu Timur tahun 2019 yang berjumlah 180 orang.

Sampel pada penelitian ini adalah sebagian remaja putri yang ada di SMA N I Martapura Kabupaten Ogan Komering Ulu Timur yang berjumlah 64 responden. Dan Teknik pengambilan sampel pada penelitian ini dilakukan secara sistematis random sampling.

\section{Data, Intrumen, dan Teknik Pengumpulan Data}

Data primer adalah data yang diperoleh langsung dari responden melalui pertemuan atau percakapan. Dalam penelitian ini data primer diambil melalui kuesioner atau wawancara langsung kepada responden (Notoatmodjo, 2012).

\section{Teknik Analisa Data}

Analisa Univariat adalah analisa data yang dilakukan untuk mengetahui distribusi frekuensi dari tiap-tiap variabel, dari variabel independen (lama menstruasi dan status gizi) dan variabel dependen (anemia pada remaja putri).

Analisa Bivariat adalah analisa ini bertujuan untuk melihat hubungan antara dua variabel yaitu: variabel dependen yaitu kejadian anemia pada remaja putri dengan variabel independen lama menstruasi dan status gizi dengan menggunakan uji statistic Chi-Square dengan batas kemaknaan $\alpha=0,05$. Keputusan hasil statistic diperoleh dengan cara membanding $P$ value dengan $\alpha$ keputusannya hasil uji statistik, yaitu :

1. Apabila $P$ value $\leq \alpha=0,05$ berarti ada hubungan yang signifikan antara variabel independen dengan variabel dependen.

2. Apabila $P$ value $>\alpha=0,05$ berarti tidak ada hubungan yang signifikan antara variabel independen dengan variabel dependen (Notoatmodjo, 2012). 


\section{HASIL PENELITIAN}

Tabel 1. Distribusi Frekuensi Dan Persentase Berdasarkan Kejadian Anemia Pada Remaja Putri kelas XI di SMA N I Martapura Kabupaten Ogan Komering Ulu Timur Tahun 2019.

\begin{tabular}{llll}
\hline $\begin{array}{l}\mathrm{N} \\
\mathrm{o}\end{array}$ & Anemia & Frekuensi & $\%$ \\
\hline 1 & Ya & 18 & 28,1 \\
\hline 2 & Tidak & 46 & 71,9 \\
\hline & Jumlah & 64 & 100 \\
\hline
\end{tabular}

Berdasarkan tabel 1 bahwa kejadian anemia sebanyak $18(28,1 \%)$ reponden sedangkan yang tidak anemia sebanyak $46(71,9 \%)$ rerponden.

Tabel 2. Distribusi Frekuensi Dan Persentase Berdasarkan Kejadian Lama Menstruasi Pada Remaja Putri Kelas XI di SMA N I Martapura Kabupaten Ogan Komering Ulu Timur Tahun 2019.

\begin{tabular}{llll}
\hline No & Lama Menstruasi & Frekuensi & $\%$ \\
\hline 1 & Panjang & 18 & 28, \\
& & & 1 \\
\hline 2 & Normal & 46 & $\begin{array}{l}71, \\
9\end{array}$ \\
& & & 100 \\
\hline & Jumlah & 64 & \\
\hline
\end{tabular}

Berdasarkan tabel 2 bahwa responden yang mengalami lama menstruasi Panjang sebanyak $28(28,1 \%)$ reponden, sedangkan yang lama menstruasi yang normal sebanyak $46(71,9 \%)$ rerponden.

Tabel 3. Distribusi Frekuensi Dan Persentase Berdasarkan Kejadian Status Gizi Pada Remaja Putri Kelas XI di SMA N I Martapura Kabupaten Ogan Komering Ulu Timur Tahun 2019.

\begin{tabular}{clcc}
\hline No & Status Gizi & Frekuensi & $\%$ \\
\hline 1 & Tidak Normal & 26 & 40,6 \\
\hline 2 & Normal & 38 & 59,4 \\
\hline & Jumlah & 64 & 100 \\
\hline
\end{tabular}

Berdasarkan tabel 3 bahwa responden yang status gizi tidak normal sebanyak $26(40,6 \%)$ reponden, sedangkan status gizi normal sebanyak $38(59,4 \%)$ responden.
Tabel 4. Hubungan Lama Menstruasi Dengan Kejadian Anemia Pada Remaja Putri Kelas XI di SMA N I Martapura Kabupaten Ogan Komering Ulu Timur Tahun 2019.

\begin{tabular}{|c|c|c|c|c|c|c|c|c|}
\hline \multirow{3}{*}{$\begin{array}{c}\text { Lama } \\
\text { Menstuasi }\end{array}$} & \multicolumn{4}{|c|}{ Anemia } & & & \multirow{3}{*}{$\begin{array}{c}\text { p. } \\
\text { Value }\end{array}$} & \multirow{3}{*}{$\begin{array}{c}O R \\
95 \% \\
C I\end{array}$} \\
\hline & \multicolumn{2}{|c|}{$\mathrm{Ya}$} & \multicolumn{2}{|c|}{ Tidak } & \multicolumn{2}{|c|}{ Jumlah } & & \\
\hline & $\mathrm{n}$ & $\%$ & $\mathrm{n}$ & $\%$ & $\mathrm{~N}$ & $\%$ & & \\
\hline Panjang & 9 & $\begin{array}{c}50, \\
0\end{array}$ & 9 & $\begin{array}{c}50, \\
0\end{array}$ & 18 & 100 & & \\
\hline Normal & 9 & $\begin{array}{c}18, \\
6\end{array}$ & $\begin{array}{l}3 \\
7\end{array}$ & $\begin{array}{c}80, \\
4\end{array}$ & 46 & 100 & 0,034 & 4,111 \\
\hline Jumlah & 18 & & $\begin{array}{l}4 \\
6\end{array}$ & & 64 & & & \\
\hline
\end{tabular}

Berdasarkan tabel 4 diketahui bahwa dari 18 responden dengan lama menstruasi yang panjang mengalami anemia sebanyak 9 responden $(50,0 \%)$ dan yang tidak mengalami anemia sebanyak 9 responden $(50,0 \%)$, sedangkan dari 46 responden dengan lama menstruasi normal, yang mengalamai anemia sebanyak 9 responden $(19,6 \%)$ dan yang tidak mengalami anemia sebanyak 37 responden $(80,4 \%)$.

Berdasarkan hasil uji statistik Chi-square diperoleh nilai $p$ value $=0,034$ hal ini menunjukan bahwa ada hubungan yang bermakna antara Lama Menstruasi dengan kejadian anemia pada remaja putri.

Dari hasil analisa diperoleh pula nilai $\mathrm{OR}=$ 4,111 , artinya remaja putri dengan lama menstruasi panjang mempunyai peluang sebanyak 4 kali, dibandingkan remaja putri yang normal Di SMA N I Martapura Kabupaten Ogan Komering Ulu Timur Tahun 2019.

Tabel 5. Hubungan Status Gizi dengan Kejadian Anemia pada Remaja Putri Kelas XI Di SMA N 1 Martapura Kabupaten Ogan Komering Ulu Timur Tahun 2019.

\begin{tabular}{|c|c|c|c|c|c|c|c|c|}
\hline \multirow{3}{*}{$\begin{array}{c}\text { Status } \\
\text { Gizi }\end{array}$} & \multicolumn{4}{|c|}{ Anemia } & \multirow{2}{*}{\multicolumn{2}{|c|}{ Jumlah }} & \multirow{3}{*}{$\begin{array}{c}p . \\
\text { Value }\end{array}$} & \multirow{3}{*}{$\begin{array}{c}O R \\
95 \% \\
C I\end{array}$} \\
\hline & \multicolumn{2}{|c|}{$\mathrm{Ya}$} & \multicolumn{2}{|c|}{ Tidak } & & & & \\
\hline & $\mathrm{n}$ & $\%$ & $\mathrm{n}$ & $\%$ & $\mathrm{~N}$ & $\%$ & & \\
\hline $\begin{array}{l}\text { Tidak } \\
\text { Normal } \\
\end{array}$ & 16 & 61,5 & 10 & $\begin{array}{c}38, \\
5 \\
\end{array}$ & $\begin{array}{l}2 \\
6 \\
\end{array}$ & 100 & & \\
\hline Normal & 2 & 5,3 & 36 & $\begin{array}{c}94, \\
7\end{array}$ & $\begin{array}{l}3 \\
8\end{array}$ & 100 & 0,000 & 28,800 \\
\hline Jumlah & 18 & & 39 & & $\begin{array}{l}6 \\
4\end{array}$ & & & \\
\hline
\end{tabular}


Berdasarkan tabel 5 diatas, dari 26 responden dengan status gizi tidak normal yang mengalami anemia sebanyak 16 responden $(61,5 \%)$, dan yang tidak mengalami anemia sebanyak 10 responden $(38,5 \%)$, sedangkan dari 38 responden dengan status gizi normal yang mengalami anemia sebanyak 2 responden (5,3\%), dan yang tidak mengalami anemia sebanyak 36 responden $(94,7 \%)$.

Berdasarkan hasil uji statistik Chi-square diperoleh nilai $\mathrm{p}$ value $=0,000$ hal ini menunjukan bahwa ada hubungan yang bermakna antara Status Gizi dengan kejadian anemia pada remaja putri.

Dari hasil analisa diperoleh pula nilai $\mathrm{OR}=$ 28,800 , artinya remaja putri dengan status gizi tidak normal beresiko terjadi anemia sebanyak 28-29 kali, dibandingkan remaja putri dengan status gizi yang normal Di SMA N I Martapura Kabupaten Ogan Komering Ulu Timur Tahun 2019.

\section{PEMBAHASAN}

\section{Hubungan Lama Menstruasi dengan kejadian Anemia Pada Remaja Putri}

Berdasarkan penelitian terhadap 64 responden dengan Lama Menstruasi yang panjang mengalami anemia sebanyak 9 responden $(50,0 \%)$ dan yang tidak mengalami anemia sebanyak 9 responden $(50,0 \%)$, sedangkan dari 46 responden dengan lama menstruasi normal, yang mengalamai anemia sebanyak 9 responden $(19,6 \%)$ dan yang tidak mengalami anemia sebanyak 37 responden $(80,4 \%)$.

Berdasarkan analisa bivariat hasil uji statistik Chi-square diperoleh nilai $p$ value 0,034 hal ini menunjukan bahwa ada hubungan yang bermakna antara Lama Menstruasi dengan Anemia.

Dari hasil analisa diproleh pula nilai OR = 4,111, artinya remaja putri dengan lama menstruasi panjang mempunyai peluang sebanyak 4 kali, dibandingkan remaja putri yang normal Di SMA N I Martapura Kabupaten Ogan Komering Ulu Timur Tahun 2019.

Hal ini juga sejalan dengan penelitian dengan uji Chi Square menunjukkan besarnya nilai $\mathrm{P}_{\text {value }}$ adalah $0,002(\alpha=0,05)$ dan nilai OR nya adalah 7,556. Sehingga dapat disimpulkan ada hubungan antara lama menstruasi dengan kejadian anemia pada remaja putri di SMA Muhammadiyah 7 Yogyakarta (Eka, 2016).

Hal penelitian ini sejalan dengan teori yang menyatakan bahwa, menstruasi merupakan salah satu penyebab terjadinya anemia defisiensi besi pada remaja putri. Remaja putri yang sudah mengalami menstruasi beresiko terjadi anemia defisiensi zat besi, karena jumlah darah yang hilang selama satu periode haid berkisar 20-25 cc, jumlah ini menyiratkan kehilangan zat besi sebesar 12,5-15 mg/bulan, atau kira-kira sama dengan $0,4-0,5 \mathrm{mg} / \mathrm{hari}$. Jika jumlah tersebut ditambah dengan kehilangan basal, jumlah total zat besi yang hilang sebesar $1,25 \mathrm{mg} /$ hari (Arisman, 2017).

Pada penelitian ini yang mengalami lama menstruasi panjang dengan kejadian anemia pada remaja putri yaitu disebabkan oleh jumlah darah yang hilang selama satu periode haid berkisaran 20-25 cc, jumlah ini menyiratkan zat besi sebesar 12,5-15 mg/bulan, atau kirakira sama dengan 0,4-0,5 mg/hari. Jika jumlah tersebut ditambah dengan kehilangan basal (masa subur), jumlah total zat besi yang hilang sebesar $1,25 \mathrm{mg} / \mathrm{hari}$. Dengan demikian maka zat besi dalam darah akan menjadi sangat rendah sehingga kadar hemoglobin dalam darah akan menurun.

\section{Hubungan Status Gizi Dengan Kejadian Anemia Pada Remaja Putri}

Berdasarkan penelitian terhadap 64 responden dengan status gizi tidak normal yang mengalami anemia sebanyak 16 responden (61,5\%), dan yang tidak mengalami anemia sebanyak 10 responden $(38,5 \%)$, sedangkan dari 38 responden dengan status gizi normal yang mengalami anemia sebanyak 2 responden $(5,3 \%)$, dan yang tidak mengalami anemia sebanyak 36 responden $(94,7 \%)$.

Berdasarkan analisa bivariat hasil uji statistik Chi-square diperoleh nilai $p$ value 0,000 hal ini menunjukan bahwa ada hubungan yang bermakna antara Status Gizi dengan Anemia. 
Dari hasil analisa diproleh pula nilai $\mathrm{OR}=$ 28,800, artinya remaja putri dengan Status Gizi yang tidak normal beresiko peluang sebanyak 28-29 kali, dibandingkan Status Gizi remaja putri yang normal Di SMA N I Martapura Kabupaten Ogan Komering Ulu Timur Tahun 2019.

Hal ini sejalan dengan penelitian yang berjudul Hubungan Antara Status Gizi dengan Anemia pada Remaja Putri di Sekolah Menengah Pertama Muhammadiyah 3 Semarang. Menunjukkan hasil bahwa dari 254 siswi yang dijadikan sampel dalam penelitian ini sebanyak 44 siswi. Terdapat responden dengan status gizi baik sebanyak 31 siswi (70,5\%), responden dengan status gizi kurang sebanyak 13 siswi $(29,5 \%)$. responden yang tidak anemia sebanyak 27 siswi $(61,4 \%)$, responden yang anemia sebanyak 17 siswi (38,6 \%). Responden yang status gizi baik dengan anemia sebanyak 4 siswi (12,9\%), responden yang status gizi baik tidak anemia sebanyak 27 siswi (87,1\%), responden yang status gizi kurang dengan anemia sebanyak 13 siswi (100,0 \%),dan responden yang status gizi kurang tidak anemia sebanyak 0 siswi $(0,0 \%)$. Dari hasil uji Chi-Square didapatkan nilai $p$-value $=0,000$ maka dapat disimpulkan bahwa ada hubungan yang bermakna antara status gizi dengan anemia (Cahya Daris Tri Wibowo, dkk, 2017).

Status gizi merupakan keadaan tubuh akibat pengaruh dari konsumsi makanan dan penggunaan zat-zat gizi, dibedakan menjadi gizi kurang, gizi baik dan gizi lebih (Almatzier, 2014).

Pada dasarnya anemia dipengaruhi secara langsung oleh konsumsi makanan sehari-hari yang kurang mengandung zat besi, selain faktor infeksi sebagai pemicunya. Secara umum, konsumsi makanan berkaitan erat dengan status gizi. Bila makanan yang dikonsumsi mempunyai nilai gizi yang baik, maka status gizi juga baik, sebaliknya bila makanan yang dikonsumsi kurang nilai gizinya, maka akan menyebabkan kekurangan gizi dan dapat menimbulkan anemia (Hapzah, 2012).
Peneliti menyimpulkan bahwa status gizi yang tidak normal dengan kejadian anemia pada remaja putri dikarenakan pada saat pemeriksaan IMT (BB (kg) / $\mathrm{TB}^{2}(\mathrm{~m})$ )di dapatkan hasil bahwa pada remaja putri mengalami pola makan yang tidak teratur dan makan-makanan siap saji seperti (Cfc, Burger, Donat, dan lain-lain) sehingga kurangnya mengkonsumsi makanan zat besi seperti (daging sapi dan daging lainya, kacang-kacangan, tempe), vitamin B-12 seperti (susu kedelai), dan vitamin C seperti (buah, jeruk, melon dan buah lainnya).

\section{KESIMPULAN}

Responden yang Anemia Normal (28,1\%) lebih kecil dibandingkan yang Tidak Normal (71,9\%). Responden yang Lama Menstruasi Panjang $(28,1)$ lebih kecil dibandingkan yang Normal $(71,9 \%)$. Responden yang Status Gizi Tidak Normal $(40,6 \%)$ lebih kecil dibandingkan Status Gizi Normal $(59,4)$ Di SMA N I Martapura Kabupaten Ogan Komering Ulu Timur Tahun 2019.

\section{SARAN}

1. Kepada SMA N 1 Martapura Kabupaten Ogan Komering Ulu Timur

Diharapakan kepada pihak sekolah agar selain memberikan dan meningkatkan pengawasan dan kewaspadaan pada siswi yang mengalami anemia dan juga dapat menyelenggarakan penyuluhan tentang bahaya yang bisa terjadi saat remaja.

2. Kepada Universitas Kader Bangsa

Diharapkan agar lebih memfasilitasi proses penelitian. Misalnya dengan memperbanyak buku referensi khususnya mengenai anemia pada remaja putri, metode penelitian serta bahan atau buku bacaan lainnya.

3. Bagi Peneliti

Pada penelitian ini diharapkan dapat menambah pengetahuan dan memperluas wawasan tentang asuhan kebidanan pada remaja putri yang bermutu sesuai dengan standar.

\section{UCAPAN TERIMA KASIH}

1. Kedua orang tua ku (Ayah Paijan dan Mama Ernawati). Yang slalu memberikan dukungan, semangat dan doa yang tiada hentinya. 
2. Adik2 ku tercinta (Lezya Shelmitha dan Hiyang Pananda). Terima kasih telah menjadi adik2 terbaik yang slalu memberikan semangat yang tiada hentihentinya.

3. Dosen Pembimbing Materi Ibuk $\mathrm{Hj}$. Herawati, M.Kes Rizki Amalia, SST, M.Kes Ucapan Terima Kasih Yang Tak Terhingga Untuk Waktu, Ilmu, nasehat, dan kesabaran dalam membimbing kami selama ini.

4. Dosen Staf Universitas Kader Bangsa Palembang Diploma IV Kebidanan, Terima Kasih Untuk Semua Bimbingannya.

5. SMA N I Martapura Kabupaten Ogan Komering Ulu Timur terima kasih karna telah mengizin saya untuk melakukan penelitian.

6. Terimakasih juga untuk ku persembahkan kepada keluarga dan sahabat $\mathrm{ku}$ yang senantiasa menjadi penyemangat $\mathrm{ku}$.

7. Teman-Teman sebimbingan dan seperjuangan serta teman se-almamater UKB tercinta yang telah sama-sama berjuang sampai kita bisa menyelesaikan pendidikan kita selama satu tahun di sini.

\section{DAFTAR PUSTAKA}

Almatzier, 2014 prinsip Dasar Ilmu Gizi, Jakarta : Gramedia Pustaka Utama.

Arisman, 2017. Buku Acuan Nasional Pelayanan Maternal, Jakarta : PT. Bina Pustaka Sarwono Prawirohardjo.

Cahya Daris Tri Wibowo, dkk, 2017 . Hubungan Antara Status Gizi dengan Anemia pada Remaja Putri di Sekolah Menengah Pertama Muhammadiyah 3 Semarang. Diakses pada Tanggal 2 Maret 2019. http://jurnal.unimus.ac.id/index.php/kedok teran/article/download/1298/1351.

Dinkes Prov. Sumatera Selatan, 2016, 2009. Sistem Kesehatan Nasional. Sumatera Selatan
Eka Vicky, dkk, 2016 . Hubungan Status Gizi Dan Lama Menstruasi Dengan Kejadian Anemia Pada Remaja Putri Di SMA Muhammadiyah 7 Yogyakarta.

Hapzah, 2012. Gizi pada masa pubertas. Jakarta: EGC

Notoatmodjo, S. 2012. Metodologi Penelitian Kesehatan. Jakarta: Renika Cipta.

$\begin{array}{llr}\text { 2014. } \quad \text { Riset } & \text { Kesehatan } & \text { Dasar; } \\ \text { RISKESDAS. } & \text { Jakarta: } & \text { Balitbang } \\ \text { Kemenkes RI } & & \end{array}$

Profil SMA Negeri I Martapura Kabupaten Ogan Komering Ulu Timur Tahun 2019

World Health Organization. 2013. .Maternal Mortality 